Stanisław LIS, Krzysztof SKUZA ${ }^{1}$

\author{
DOI: $10.15290 /$ ose.2015.03.75.04
}

\title{
ZMIANY EDUKACYJNYCH ASPIRACJI POLAKÓW W OKRESIE TRANSFORMACJI SYSTEMOWEJ
}

\begin{abstract}
Streszczenie
Analiza przemian postaw i aspiracji edukacyjnych Polaków i wybieranych przez nich strategii edukacyjnych w okresie transformacji systemowej jest zasadniczym celem artykułu. Kierunek zachodzacych zmian w tym obszarze jest - jak wykazano - determinowany głównie przez proces merytokratyzacji postaw społecznych. Związany jest on $z$ utrwalaniem się zasad liberalnego rynku pracy i poszerzaniem oferty instytucji edukacyjnych. Wyniki badań opinii publicznej potwierdzaja istotny wzrost znaczenia wykształcenia, kwalifikacji i umiejętności jednostek w odniesieniu sukcesu nie tylko w sferze gospodarczej, ale także w osiągnięciu prestiżu społecznego i satysfakcji osobistej. Jednakże zbyt masowe i niekontrolowane rozszerzenie podaży usług szkolnictwa wyższego może prowadzić do obniżenia poziomu i jakości kształcenia i zatrzymania się tendencji merytokratycznej.
\end{abstract}

Słowa kluczowe: merytokracja, edukacja, wykształcenie, rynek pracy, okres transformacji

\section{CHANGES IN POLES' EDUCATIONAL ASPIRATIONS DURING TRANSFORMATION PERIOD}

\section{Summary}

The main objective of the paper is to analyse the changes in the attitudes and educational aspirations of the Polish citizens, and their preferred educational strategies, that could be observed in the transformation period. As shown in the paper, the direction of change in this area is mainly determined by the process of implementing meritocracy in the Polish society. This tendency is related to the consolidation of the liberal labour market on the one hand, and the expanding offer of various educational institutions on the other. Poll results confirm a significant increase in the perceived importance of education, skills and abilities in pursuit of individual success, not only in the economic dimension, but also for achieving social prestige and personal satisfaction. However, the massive and uncontrolled expansion of the supply of higher education services can adversely affect the quality of education and stifle the meritocratic tendencies.

Key words: meritocracy, education, professional qualifications, labour market, transformation in Poland

\footnotetext{
${ }^{1}$ Prof. zw. dr hab. Stanisław Lis - Wydział Ekonomii i Stosunków Międzynarodowych, Uniwersytet Ekonomiczny w K,rakowie; e-mail: liss@uek.krakow.pl; dr Krzysztof Skuza - Wydział Ekonomii, Staropolska Szkoła Wyższa w Kielcach; e-mail: krzysztof.skuza1@gmail.com.
} 


\section{Wstęp}

Transformacja polskiej gospodarki po 1989 roku i wywołane przez nią poważne zmiany struktury rynku pracy znacząco wpłynęły na kształtowanie się postaw i aspiracji edukacyjnych pracowników. Zmiany te pokazują zarówno badania socjologiczne i sondaże prowadzone przez ostatnie dwudziestolecie, jak i codzienne obserwacje życia społecznego: wzrost liczby uczelni wyższych, zwiększająca się liczba studentów i Polaków legitymujących się wykształceniem wyższym, czy też absolwentów więcej niż jednego kierunku studiów. Obserwując młode pokolenie Polaków, mieszkających w największych miastach, można zauważyć, że stajemy się coraz lepiej wykształconym społeczeństwem profesjonalistów, nieustannie podnoszących swoje kwalifikacje. Wzrastająca społeczna percepcja wykształcenia i kwalifikacji jako czynników sukcesu i osiagnięcia wysokiego statusu społeczno-ekonomicznego wskazuje na coraz szerszą merytokratyzację postaw i strategii edukacyjnych Polaków. Funkcjonujący obecnie polski system edukacyjny ma - z założenia - eliminować nierówności społeczne związane z tzw. „gorszymi” szansami życiowymi, pochodzeniem społecznym, miejscem zamieszkania itd. Można także przyjać, że merytokracja będzie służyć nie tylko bardziej profesjonalizującej się warstwie inteligencji, ale również - per saldo - dobru ogółu społeczeństwa. Współczesna „gospodarka oparta na wiedzy”, czyli kolejny etap rozwoju gospodarki rynkowej, oparta jest w znacznej mierze na procesach konkurencyjnych i kompetencyjnych, co ma prowadzić w efekcie do wzrostu innowacyjności. Ideologia liberalna zakłada, że przy początkowej równości szans, nierówność w dystrybucji dochodów, a także wynagradzanie za indywidualne kwalifikacje jednostki, jej konkurencyjność $i$ indywidualne zasługi nie moga być wykluczone. Czy zatem merytokracja może wdrażać nowe zasady podziałów społecznych? Czy w percepcji Polaków wprowadza ona uprawomocnienie dla społecznych nierówności, zmian w strukturze zawodowej oraz mechanizmie różnicowania i dystrybucji dochodów? Niniejszy artykuł stanowi próbę odpowiedzi na te pytania.

\section{Przemiany w sferze edukacji po 1989 roku}

Prowadzone badania socjologiczne wykazały, że w społeczeństwach postkomunistycznych przemiany w obszarze edukacji były ściśle powiazzane z całym przebiegiem ogólnej transformacji ustrojowej - z jej tempem i zakresem [Pierwsza dekada..., 2001, s. 200-202]. Jak pisał Wiatr: priejscie do gospodarki rynkowej i wrrost rangi wylksztatcenia w ksztattowaniu posycji spolecznej owocuje takim pedem do edukacji, jakiego nie byto w Polsce juz od dawna - zapewne od pierwssych kilkunastu lat Polski Ludowej [Wiatr, 1999, s. 115]. Mało innowacyjny, niekonkurencyjny system gospodarczy w PRL nie dostarczał bodźców do wprowadzania innowacji w sferze edukacyjnej, a gwarantowane ustawa zatrudnienie stanowiło istotny - w zasadzie - antybodziec do podnoszenia kwalifikacji pracowników. Opiekuńcze państwo socjalistyczne zapewniało otwarty dostęp do elementarnej edukacji dla wszystkich obywateli (model edukacji popularnej), przy jednoczesnym zastosowaniu nieraz arbitralnych (uznaniowych) mechanizmów selekcji na 
studia wyższe (model ograniczonej edukacji). Mimo że status społeczny absolwentów uczelni był nieco wyższy niż przeciętny, to zwłaszcza w latach 1945-1970 z powodu dominującej roli pozaedukacyjnych dróg awansu (pozycja jednostki w strukturze partyjno-związkowej) nie stanowili oni elity ani zawodowej, ani politycznej, a posiadanie wyższego wykształcenia nie gwarantowało dochodów wiele wyższych niż średnia krajowa [Pierwsza dekada..., 2001, s. 203]. W ówczesnym, sterowanym centralnie układzie społeczno-ekonomicznym system szkolnictwa i kształtowana w jego ramach struktura wykształcenia były determinowane przede wszystkim potrzebami systemu zatrudnienia w poszczególnych sektorach: preferowane były branże wielkoprzemysłowe, których rozwój wynikał z obowiązującej w owym czasie koncepcji rozwoju społeczno-gospodarczego. Proegalitarna ideologia oraz system przywilejów płacowych, które miały motywować do realizacji planów produkcji w państwowych zakładach, a także licznie narzucane formy racjonowania dóbr deficytowych praktycznie uniemożliwiały kształtowanie się zarobków według zasady merytokracji. Ówczesne korzyści płynące z wyższego wykształcenia tak podsumowuje L. Beskid: przy myrównanych zarobkach, lepsze wyksztatcenie dawało dodatkowe szanse na ,ustawienie sie” $i$ dostep do deficytowych dóbr w systemie reglamentaci [Beskid, 1999, s. 112]. Brak istotnego związku pomiędzy poziomem kwalifikacji a poziomem konsumpcji oraz zamożności przynosił tylko negatywne skutki dla ogólnej sprawności ekonomicznej, zarówno na poziomie jednostkowym, jak i makrospołecznym [Pierwsza dekada..., 2001, s. 200-201].

Urynkowienie gospodarki zatrzymało ten proces i wpłynęło znacząco na wszystkie sfery życia społeczno-ekonomicznego w kraju. Zasadnicze zmiany, jakie zaszły w systemie polskiego szkolnictwa po 1989 roku, związane były przede wszystkim ze zniesieniem monopolu państwa w kształceniu młodzieży i poddaniu części szkolnictwa działaniu mechanizmu rynkowego, jak również z próbami sprzężenia programów nauczania z potrzebami wynikającymi z nowej sytuacji gospodarczej. Rozwój liberalnego rynku pracy opartego na zasadach konkurencji podmiotów gospodarczych oraz rozbudowa prywatnego sektora zatrudnienia zaczęły przyczyniać się do przywracania związku pomiędzy poziomem i jakością wykształcenia a polepszaniem sytuacji materialnej społeczeństwa. W warunkach gospodarki wolnorynkowej to właśnie wykształcenie i kwalifikacje stanowią strategiczne zasoby, które w zdecydowanej mierze decydują o pozycji jednostki na rynku pracy. Zdobycie owych zasobów wymaga jednak znacznych inwestycji, gdyż proces edukacji trwa wiele lat, co może oznaczać opóźnienie momentu wejścia na rynek pracy, a zatem wprowadza konieczność odraczania oczekiwanych nagród. Wyniki badań opinii społecznej pod koniec lat dziewięćdziesiątych ubiegłego wieku wskazywały, że w świadomości Polaków po 1989 roku [Równość jyciowych..., 1999] droga do awansu zawodowego i sukcesu życiowego zaczęła wiązać się ze zdobywaniem wykształcenia, a tym samym powoli i stopniowo słabły dominujące w PRL mechanizmy protekcji partyjnej i przekonania o skuteczności wyłącznie „dojśćc i „pleców” w osiaganiu sukcesu. Na kolejnym etapie, wyznaczonym przez przystapienie Polski do Unii Europejskiej, ugruntowało się przekonanie o znaczeniu kwalifikacji i wykształcenia jako czynników służących osiągnięciu przez jednostkę pożądanej pozycji zawodowej [Rola wykeształcenia..., 2009], a co więcej, do głosu doszła szersza problematyka budowy gospodarki innowacyjnej i konkurencyjnej, tzw. gospo- 
darki opartej na wiedzy (knowledge based economy). Strategia Lizbońska zakłada słusznie, że ten model gospodarki stanie się główną siłą napędową na europejskim rynku dóbr $i$ usług. Przyjęcie tego systemu gospodarczego wiąże się również z przyjęciem pewnego modelu społeczeństwa: pociaga za sobą konieczność zbudowania bardzo szerokiej klasy wykwalifikowanych pracowników (społeczeństwa profesjonalistów), którzy będa odczuwać potrzeby rozwijania swoich umiejętności i podnoszenia kompetencji, a w efekcie - wkład ich pracy będzie decydować o innowacyjności i konkurencyjności gospodarki. Współczesny model gospodarki opartej na wiedzy może stanowić doskonała ilustrację założeń społeczeństwa merytokratycznego. Analiza zmian w zakresie wykorzystania wykształcenia w pracy oraz odczuwanych potrzeb podnoszenia swoich kwalifikacji wskazuje na aktualne bariery, ale także możliwości rozwijania w polskim społeczeństwie gospodarki opartej na wiedzy.

\section{Merytokracja w nurcie funkcjonalnej teorii nierówności społecznych}

Po 1989 roku w strategiach życiowych Polaków, w ich przekonaniach i podejmowanych działaniach coraz wyraźniej można było dostrzec przejawy merytokracji, której zasady w pewnym stopniu zaczęły wyznaczać nie tylko nowy porządek zróżnicowań materialnych, lecz również kierunek dalszych przemian w kraju². Przesłanek dla użyteczności merytokracji można doszukać się m.in. w funkcjonalistycznej koncepcji nierówności społecznych Davisa i Moore’a [Elementy teorii..., 1975, s.464-476]. Autorzy ci, posługując się dwiema kategoriami: funkcjonalną ważnością danej pozycji oraz wymaganymi kwalifikacjami dla jej zajęcia, uzasadniają funkcjonalną konieczność rozwarstwienia. Większa ważność pozycji podnosi jej rangę, ale jednocześnie wymaga od pretendujących do niej jednostek ponoszenia większych nakładów: wymagana jest większa odpowiedzialność oraz odpowiednio wyższe kwalifikacje, a zatem i dłuższy okres kształcenia. Inwestowanie we własne wykształcenie powinno zwrócić się w postaci adekwatnie wyższych dochodów [Domański, 2004a, s. 287-292]. Zdaniem Davisa i Moore’a: odmienne uynagradzanie różnych posycji społecznych jest systemem, džęei ketóremu wiekeszość jednostek o odpowiednich kwalifikacjach jest pozyskiwana na różnorodne stanowiska i motywowana do wykonywania obowiqzkón anviazanych z ich zajmowaniem w sposób skuteczny $i$ wydajny [Hamilton, Hirszowicz, 1995, s. 29]. W koncepcji Davisa i Moore’a nierówności dochodów i prestiżu są wynikiem działania praw rynku, a dokładnie: relacji między podażą a popytem na najbardziej cenione zasoby, w tym przypadku wysokie wykształcenie.

\footnotetext{
${ }^{2}$ Merytokracja (merytokratyzm) jest rozumiana jako system wynagradzania jednostek za osobiste „zasługi”(czyli merits), obejmujące: zdolności, talent, kwalifikacje zawodowe i inne „nakłady” ponoszone przez jednostki. W tak funkcjonującej strukturze pozycja społeczna zależy od cech osiaganych, a nie przypisanych jednostce. Za wskaźniki zachodzącej merytokratyzacji postaw i strategii życiowych Polaków uznano m.in.: powszechnie deklarowany wzrost wartości wykształcenia jako warunku sukcesu życiowego, podwyższanie aspiracji edukacyjnych, które znajduje odbicie w działaniach edukacyjnych Polaków, a także rosnącą w społeczeństwie polskim akceptację wzorca dystrybucji dochodów opartego na dopasowywaniu poziomu zarobków do wykształcenia i pozycji zawodowej jednostek oraz przekonanie o funkcjonalności merytokratycznego systemu zróżnicowania dochodów.
} 
Teoria Davisa i Moore’a była krytykowana za nieuwzględnianie nierównego dostępu do kanałów rekrutacji i środków kształcenia oraz ignorowanie możliwości dziedziczenia pozycji [Elementy teorii..., 1975, s. 477-487]. Jeśli chodzi o nierówny dostęp do edukacji, to rozwiazaniem stosowanym w okresie PRL było przyznawanie punktów preferencyjnych podczas rekrutacji na studia wyższe: jednak zdarzało się, że w takim systemie jednostki bardziej zdolne nieraz przegrywały z kandydatami z promowanych środowisk (z rodzin rolniczych czy robotniczych). Mimo to, jak wynika z jednego z sondaży przeprowadzonych w 1984 roku, zasada „punktów za pochodzenie" była akceptowana większościa głosów jedynie przez rolników (46\%), [Opinie o zasadach..., 1984]. Wśród robotników oraz pracowników umysłowych przeważał pogląd przeciwny tej zasadzie: otóż 53\% robotników, $65 \%$ pracowników umysłowych bez wyższego wykształcenia oraz $69 \%$ pracowników umysłowych z wyższym wykształcenia uważało, że na studia wyższe powinno się przyjmować wyłącznie na podstawie wyników uzyskanych na egzaminach. W społeczeństwie panowała - jak widać - opinia, że pochodzenie społeczne wpływa na możliwości osiagnięcia sukcesu życiowego oraz przekonanie o nierówności szans związanych z tą cechą [Równość sycionych..., 1999]. Jako najmniej korzystne oceniano predyspozycje dzieci rolników, w tym inicjatywę i przedsiębiorczość. Jakkolwiek za bardzo ważne uznawano cechy związane z pochodzeniem społecznym (zamożność rodziców $-87 \%$, miejsce zamieszkania $-76 \%$ ), to w hierarchii ważności źródeł sukcesu wyprzedziły je charakterystyczne dla funkcjonalistycznej koncepcji nierówności społecznych cechy merytokratyczne (wykształcenie, kwalifikacje), które stanowią osobisty wkład w osiaganie sukcesu. W przeprowadzonym w 2000 roku sondażu „Wykształcenie - szansa na sukces czy przeżytek" zdobycie wykształcenia znalazło się na trzecim miejscu w hierarchii spraw koniecznych dla życiowego powodzenia - wymienione przez $65 \%$ badanych, przed ciekawa praca $(57 \%)$ i dobrymi warunkami materialnymi (52\%), [Wyksz̧tatcenie - szansa..., 2000].

\section{Wzrost aspiracji edukacyjnych Polaków}

Obserwowany wzrost aspiracji edukacyjnych Polaków to jeden z ważniejszych efektów przemian społecznych po 1989 roku: wykształcenie jest traktowane przez większość obywateli nie tylko jako wartość deklarowana, ale również jako wartość respektowana, co oznacza, że przekonaniom towarzyszą konkretne działania, które wpłynęły na podnoszenie się poziomu wykształcenia społeczeństwa. Zdaniem Wiatra: narastajaca fala ekspansji edukacyjnej jest jednym ₹ najcenniejszych efektów zmian ustrojonych ostatniego driesieciolecia [Wiater, 1999, s. 115]. Do pierwszej grupy czynników, wpływających na dynamizm zjawiska nazywanego „skokiem edukacyjnym”, należy zaliczyć coraz bogatszą ofertę prywatnego sektora w szkolnictwie wyższym oraz rozwój studiów „komercyjnych" w publicznych uczelniach wyższych [Życie codżienne..., 2003, s.13-27]. Natomiast przyczyn drugiego rodzaju należałoby dopatrywać się w sferze podmiotowej, tj. w świadomości Polaków, że wykształcenie jest czynnikiem warunkującym osiagnięcie życiowego sukcesu. O dynamice zjawiska świadczą dane ze spisów powszechnych [Na- 
rodony Spis Powszechny..., 2002; Narodony Spis Powszechny..., 2012]. W 1988 roku wykształcenie poniżej podstawowego miało 6,5\% Polaków, w 2001 roku było to 4,9\%, natomiast w 2011 roku - 1,4\% zbiorowości. Wykształceniem podstawowym legitymowało się w 1988 roku około 38, 8\% ogólu społeczeństwa, w 2001 roku - 28,2\%, zaś w 2011 roku - 23,8\% populacji. W okresie 1988-2011 zmalał odsetek osób posiadających wykształcenie zawodowe, tymczasem wzrósł w badanej populacji udział osób z wykształceniem średnim i policealnym. Szczególnie ważny, będący wyrazem tzw. polskiej rewolucji edukacyjnej, jest wzrost liczby osób z wykształceniem wyższym z 6,5\% w 1988 roku do 11,3\% w 2002 roku i do 16,8\% zbiorowości w 2011 roku. Warto w tym miejscu zauważyć, że w roku akademickim 1990/1991 w Polsce studiowało 404 tys. osób (z czego na studiach dziennych 312 tys.), a studia doktoranckie odbywało w tym samym roku 2,7 tys. osób [Rocznike Statystyczny, 1991]. Dla porównania w roku 2001/2002 studiowało już 1,7 mln osób (z czego 765 tys. na studiach dziennych), a na studiach doktoranckich 28,3 tys. osób. Z kolei w roku akademickim 2009/2010 było ponad 1,9 mln studentów i 35,7 tys. doktorantów. W następnych latach można było zaobserwować zmniejszanie się liczby osób studiujących na wyższych uczelniach i w roku 2012/2013 liczba studentów spadła do 1,7 mln [Mały Rocznike Statystycżny, 2013]. Jednak proces ten w dużym stopniu należy wiązać $\mathrm{z}$ niżem demograficznym.

Z danych opublikowanych przez CBOS wynika, że po 1989 roku systematycznie rosła w Polsce liczba osób przekonanych, że warto zdobywać wykształcenie: z 76\% wskazań w 1993 roku do 93\% w 2004 roku. Natomiast od 2009 roku można odnotować stopniowy spadek przekonania o wartości wykształcenia - do poziomu $89 \%$ w 2009 roku i 82\% w 2013 roku. Aktualnie odsetek badanych, uważających, że warto się uczyć, jest o 11 punktów niższy niż w roku 2004 i 2007 [W ₹rost aspiraciji..., 2004; Cyy warto..., 2007; Rola wylksztatcenia..., 2009; Wykesztatcenie ma..., 2013]. Dane z sondaży CBOS przeprowadzonych od 1993 roku do 2013 roku przedstawiono w tabeli 1.

Zaprezentowane dane liczbowe obrazuja procesualny charakter zmian opinii Polaków na temat wartości wykształcenia. Wraz z postępującymi zmianami społecznoekonomicznymi w Polsce, w trzecim dziesięcioleciu funkcjonowania gospodarki wolnorynkowej, zaczęła powiększać się grupa osób podających w wattpliwość sens zdobywania wykształcenia. Według sondażu CBOS z 2013 roku [Studia my ższe..., 2013] ponad połowa Polaków (57\%) uważała, że dyplom wyższej uczelni ma ograniczoną wartość na rynku pracy. Znacząca większość społeczeństwa (78\%) podzielała przekonanie o umasowieniu kształcenia wyższego. Dość powszechna była także opinia o spadku wartości wyższego wykształcenia oraz o wyraźnym obniżeniu jakości kształcenia uniwersyteckiego - pogląd taki wyraziło około $47 \%$ ankietowanych. Najbardziej negatywne opinie na temat wartości i jakości wykształcenia wyższego prezentowali ankietowani z wyższym wykształceniem - około $74 \%$ badanych. Warto zauważyć, że zmieniające się opinie na temat wartości i jakości wykształcenia nie przekładają się jednak na zmianę aspiracji edukacyjnych Polaków - popyt na wyższe wykształcenie jest w naszym kraju wciąż bardzo duży. 
TABELA 1.

Opinie na temat wartości wykształcenia według badań CBOS w latach 1993-2013

\begin{tabular}{|c|c|c|c|c|c|c|c|c|c|c|c|c|}
\hline \multirow{3}{*}{$\begin{array}{c}\text { Czy Pana(i) } \\
\text { zdaniem, warto } \\
\text { obecnie w Pol- } \\
\text { sce zdobywać } \\
\text { wykształcenie, } \\
\text { uczyć się czy też } \\
\text { nie warto? }\end{array}$} & \multicolumn{12}{|c|}{ Wskazania respondentów według terminów badań } \\
\hline & \multicolumn{2}{|c|}{ XI 1993} & \multicolumn{2}{|c|}{ X 2002} & \multicolumn{2}{|c|}{ IV 2004} & \multicolumn{2}{|c|}{ IV 2007} & \multicolumn{2}{|c|}{ XI 2009} & \multicolumn{2}{|c|}{ IV 2013} \\
\hline & \multicolumn{12}{|c|}{$(w \%)$} \\
\hline $\begin{array}{c}\text { Zdecydowanie } \\
\text { warto }\end{array}$ & 42 & \multirow{2}{*}{76} & 66 & \multirow{2}{*}{91} & 76 & \multirow{2}{*}{93} & 70 & \multirow{2}{*}{93} & 63 & \multirow{2}{*}{89} & 49 & \multirow{2}{*}{82} \\
\hline Raczej warto & 34 & & 25 & & 17 & & 23 & & 26 & & 33 & \\
\hline Raczej nie warto & 16 & \multirow[b]{2}{*}{20} & 5 & \multirow[b]{2}{*}{7} & 4 & \multirow[b]{2}{*}{5} & 4 & \multirow[b]{2}{*}{5} & 8 & \multirow[b]{2}{*}{10} & 13 & \multirow[b]{2}{*}{16} \\
\hline $\begin{array}{c}\text { Zdecydowanie nie } \\
\text { warto }\end{array}$ & 4 & & 2 & & 1 & & 1 & & 2 & & 3 & \\
\hline $\begin{array}{c}\text { Trudno } \\
\text { powiedzieć }\end{array}$ & 4 & 4 & 2 & 2 & 2 & 2 & 2 & 2 & 1 & 1 & 2 & 2 \\
\hline
\end{tabular}

Źródło: [Wyksżtakcenie ma žnaczenie?, 2013].

W omawianych sondażach można również znaleźć motywy zdobywania wykształcenia. Za najważniejszy motyw badani uznawali wysokie zarobki (w 1993 roku uważało tak 58\% respondentów, w 2002 roku $-70 \%$, a w 2007 roku 65\% respondentów). W 2013 roku głównym motywem dla 63\% respondentów była chęć zdobycia „lepszej pracy" - lepszej pod względem warunków finansowych, jak i pozapłacowych (zgodnej z zainteresowaniami, lekkiej), [Studia wyæ̇sze..., 2013]. Za równie ważny powód uznawano także możliwość zatrudnienia w ogóle, która była w 2002 roku wymieniana na trzecim, a w 2004 roku na czwartym miejscu (odpowiednio: 36 i 41\%). Natomiast w 2007 roku Polacy wymieniali tę przesłankę już na szóstym miejscu. W sondażu z 2013 roku kategoria ta została włączona w szerszą kategorię - „pozycja na rynku pracy" - i jako ważną przyczynę uznało ją tylko 14\% respondentów [Studia wy šrze..., 2013]. Analizując wyniki omawianych badań, można stwierdzić, że po 2000 roku znaczenie takich motywów, jak zdobycie interesującego zawodu czy też uzyskanie szacunku społecznego wykazywało tendencję spadkowa. Natomiast nie uległy osłabieniu główne motywy zdobywania wykształcenia, a więc osiaganie niezależności finansowej i rozwój intelektualny respondentów. Jak już uprzednio wspomniano, Polacy przykładają szczególną wagę do wykształcenia swoich dzieci, uważając je za najważniejszą determinantę decydującą o ich przyszłości. Zasadnicze motywy edukacji dzieci są ściśle związane z poziomem ich własnego wykształcenia: im lepiej są wykształceni rodzice, tym częściej chcieliby, aby ich dzieci ukończyły studia. Ta zależność była widoczna w odpowiedziach respondentów ze wszystkich grup wyróżnionych ze względu na poziom wykształcenia. Jednak w opiniach polskiego społeczeństwa można również było dostrzec pozostałości poprzedniego systemu - i niestety obecnej w kraju współczesnej patologii - iż protekcja była i jest podstawowym czynnikiem warunkującym awans zawodowy i płacowy. Na półmetku młodej, polskiej demokracji ,znajomości i pro- 
tekcja" były wciąż wymieniane wśród czynników mających bardzo duży wpływ na sukces życiowy (90\%), lecz nie były już one uważane za warunek wystarczający, jeśli nie są poparte wysokimi kwalifikacjami i umiejętnościami, które musi posiadać osoba protegowana [O stylach ṡycia..., 1997; Równość życiowych..., 1999].

Duża liczba respondentów podzieliła opinię, że jak na potrzeby współczesnej gospodarki, duża grupa osób jest niedostatecznie i nieodpowiednio wykształcona. Dane CBOS z 2002 roku ukazały spadek odsetka Polaków odczuwających satysfakcję ze swojej ścieżki kształcenia - z 42\% w 1993 roku do 24\% w 2002 roku, a jednocześnie wzrost niezadowolonych z 47\% do 70\% [Polacy o swoim..., 2002]. Wśród grup społeczno-zawodowych uzyskane wykształcenie uważali za satysfakcjonujące przede wszystkim przedstawiciele kadry kierowniczej (43\%), a w pozostałych kategoriach odsetek ten nie przekraczał 25\%. Jednak po 2004 roku można było zaobserwować nieznaczny wzrost odsetka osób zadowolonych z poziomu swojego wykształcenia: z 33\% w 2004 roku do 34\% w 2009 roku. Fakt ten należy wiązá z ogólnym wzrostem poziomu wykształcenia w Polsce. Niezadowolenie z własnego, najczęściej zbyt niskiego, wykształcenia (55\% w 2002 roku i 51\% w 2009 roku) mogło wynikać z przekonania osób o niskich kwalifikacjach, że ich możliwości awansu i osiągnięcia sukcesu ekonomicznego są bardzo ograniczone, gdyż nie spełniają oni wymogów selekcji merytokratycznej, które od 1989 roku stopniowo obejmują coraz większy obszar rynku pracy, na którym sa poszukiwani pracownicy wykształceni, ale i o dużym potencjale dalszego rozwoju, zdobywania dodatkowych kwalifikacji [Rola wykesztatcenia..., 2009].

W tabeli 2. przedstawiono wyniki badań sondażowych z 2009 roku dotyczace deklarowanej przez osoby badane chęci podnoszenia swoich kwalifikacji w zależności od subiektywnie ocenianego własnego braku kwalifikacji bądź wystarczających kwalifikacji dla wykonywanej aktualnie pracy zawodowej [Rola wykeształcenia..., 2009].

TABELA 2.

\section{Postrzeganie własnych kwalifikacji przez Polaków i gotowość do ich podnoszenia}

\begin{tabular}{|c|c|c|c|}
\hline $\begin{array}{c}\text { Czy odczuwa/ odczuwał(a) } \\
\text { Pan(i), że brakuje Panu(i) } \\
\text { wykształcenia, kwalifikacji } \\
\text { w obecnej/ ostatniej pracy } \\
\text { zawodowej? }\end{array}$ & \multicolumn{3}{|c|}{$\begin{array}{c}\text { Czy obecnie był(a)by Pan(i) gotowy(a) podwyższyć } \\
\text { poziom swojego wykształcenia lub uzupełnić swoje } \\
\text { kwalifikacje? }\end{array}$} \\
\cline { 2 - 4 } & Tak & Nie & $\begin{array}{c}\text { Trudno } \\
\text { powiedzieć }\end{array}$ \\
\cline { 2 - 4 } & \multicolumn{3}{|c|}{ (w \%) } \\
\hline Zdecydowanie tak & 50 & 50 & 0 \\
Raczej tak & 49 & 49 & 2 \\
Raczej nie & 44 & 52 & 2 \\
Zdecydowanie nie & 46 & 52 & 15 \\
Trudno powiedzieć & 44 & 41 & \\
\hline
\end{tabular}

Źródło: [Rola wykšstałcenia $i$ zmiany w jej społecznym postrzeganiu w latach 1993-2009, 2009].

Chęć zdobywania dodatkowych kwalifikacji, podnoszenia swojego wykształcenia przez osoby aktywne zawodowo jest miarą społecznego potencjału dla rozwoju gospo- 
darki opartej na wiedzy - społeczeństwa profesjonalistów. Badania sondażowe przeprowadzone przez CBOS w grudniu 2009 roku wykazały, że prawie połowa Polaków (48\%) jest gotowa podnosić swoje kwalifikacje, jednak niemal tyle samo badanych (49\%) nie podjęłoby się dokształcania, nawet gdyby mieli takie możliwości. Wolę podnoszenia swoich kwalifikacji i dokształcania się deklarowały głównie osoby młode i lepiej wykształcone, gdyż możliwe do osiagnięcia zyski przewyższaja koszty uzyskania kwalifikacji. Dla osób młodych, u progu kariery zawodowej, zdobywanie dodatkowych kwalifikacji oznacza większy wpływ na własną karierę zawodową i poszerzenie możliwości awansu [Rola wyłkształcenia..., 2009].

\section{Wykształcenie a struktura zatrudnienia i dochodów}

Jak słusznie zauważa Ziółkowski: Zdobycie nyższego mykształcenia stało sie podstawonym źródtem usyskiwania wysokich dochodów (statystycznie nie tylko w stosunku do robotnikón wykwalifikowanych, ale takize - wbrew potocznym stereotypom - w stosunku do prywatnych przedsiebiorcón), a Polska staje sie powoli społeczeństwem merytokratycznym [Ziółkowski, 2005, s. 37]. W Polsce po 1989 roku hierarchia zarobków zaczęła upodabniać się do hierarchii występującej w krajach zachodnich; jeśli uwzględnimy kilkanaście podstawowych kategorii społeczno-zawodowych, to okaże się że w miarę rozwoju gospodarczego na frontalne pozycje przesunęły się najwyższe kadry kierownicze, czyli dyrektorzy firm i urzędów oraz kategorie inteligencji nietechnicznej, obejmujące: lekarzy, prawników, naukowców, przedstawicieli świata kultury, specjalistów bankowości i marketingu. Jednocześnie można zaobserwować relatywne obniżenie się dochodów w rodzinach, których źródło utrzymania lokuje się w sektorze średniego i drobnego biznesu poza rolnictwem. Właściciele firm, którzy sytuowali się na szczycie piramidy zarobków w poprzednim ustroju, w latach dziewięćdziesiątych systematycznie przesuwali się w dół: obecnie zajmują oni trzecia pozycję, za kierownikami i inteligencją nietechniczną [Domański, 2004b, s. 60-67].

Proces zmian zachodzących w hierarchii dochodów autorzy polscy analizują na wielu płaszczyznach. Jeden z aspektów może być związany z przebiegiem cyklu koniunkturalnego, w którym kryzys następuje po okresie prosperity i obejmuje degradację środowisk biznesu: kategoria właścicieli firm stała się głównym beneficjentem transformacji po 1989 roku. Jednak na szczególną uwagę zasługują wszystkie te procesy, które świadczą o wzroście merytokracji w społeczeństwie polskim: chodzi o przesunięcia w hierarchii dochodów, odzwierciedlające te zamiany we wzorach dystrybucji, które wynikaja przede wszystkim ze wzrostu wpływu wykształcenia i pozycji zawodowej. Dyplom wyższej uczelni zawsze gwarantował większe korzyści finansowe niż zakończenie nauki na niższych szczeblach kształcenia. Ukończenie studiów wyższych zapewnia, zdaniem wspomnianego autora, „czysty zysk”, a ten można traktować jako wielkość finansowego zwrotu za poniesione nakłady na zdobycie wykształcenia, które ponosi jednostka. Kategorię „czystego zysku” zaczęto mierzyć w 1982 roku, w czasie gdy opłacalność podejmowania studiów wyższych w Polsce była bardzo niska. Udział czystego zysku w dochodach obliczono wtedy na $18 \%$, co oznaczało, że oso- 
by z wyższym wykształcenie, po wyłączeniu różnic wynikających z: płci, wieku, miejsca zamieszkania i zajmowanego stanowiska oraz działu i sektora gospodarki, zarabiały średnio o 18\% więcej od średniej krajowej. Wyniki kolejnych badań przynosiły wzrost udziału czynnika „czystego zysku” w wyjaśnianiu zróżnicowania dochodów: w 1992 roku wynosił on 24\%, a w 2002 roku 46\%, co świadczyło o tym, że wykształcenie zaczęło przekładać się na coraz wyższe zarobki [Domański, 2004b, s. 62--65].

Wyniki przeprowadzanych w ostatnim dziesięcioleciu badań sondażowych, dotyczących wpływu wykształcenia na życie zawodowe w Polsce, wskazywały na poziom wykorzystania zasobów wiedzy na rynku pracy. Badania z 2009 roku dowiodły, że w okresie transformacji można było zaobserwować wzrost odsetka osób, które deklarowały duży wpływ wykształcenia na ich karierę zawodową (do 49\%), co potwierdziło coraz lepsze wykorzystywanie na polskim rynku pracy potencjału wynikającego z posiadanych kwalifikacji - wiedzy i wykształcenia. Jednocześnie, zgodnie z danymi sondażowymi, w tym samym czasie odsetek osób, które utrzymywały, że poziom wykształcenia miał mały wpływ na ich życie zawodowe - w zasadzie - nie zmienił się i wyniósł około 30\% badanych. Natomiast można dostrzec wzrost przekonania, że wykształcenie ma duży wpływ na dorobek materialny: w 1994 roku uważało tak 30\%, a w 2009 roku 42\% badanych. Równocześnie obniżył się odsetek osób reprezentujących pogląd, że wykształcenie w bardzo małym stopniu warunkuje wpływ lub w ogóle nie ma wpływu na poziom dochodów ludności (z 45\% w 1994 roku do 37\% w 2009 roku), (tabela 3.).

TABELA 3.

\section{Opinie na temat wpływu wykształcenia na różne dziedziny życia w latach 1994-2009}

\begin{tabular}{|c|c|c|c|c|c|c|c|c|c|c|c|c|c|c|}
\hline \multirow{4}{*}{$\begin{array}{c}\text { Wpłw } \\
\text { wykształ- } \\
\text { cenia na } \\
\text { różne } \\
\text { dziedziny } \\
\text { życia }\end{array}$} & \multicolumn{14}{|c|}{ Oceniane dziedziny } \\
\hline & \multicolumn{2}{|c|}{$\begin{array}{l}\text { dorobek } \\
\text { materialny }\end{array}$} & \multicolumn{2}{|c|}{$\begin{array}{l}\text { uznanie } \\
\text { innych }\end{array}$} & \multicolumn{2}{|c|}{$\begin{array}{l}\text { dotych- } \\
\text { czasowe } \\
\text { życie } \\
\text { rodzinne }\end{array}$} & \multicolumn{2}{|c|}{$\begin{array}{l}\text { dotych- } \\
\text { czasowe } \\
\text { życie } \\
\text { zawodowe }\end{array}$} & \multicolumn{2}{|c|}{$\begin{array}{c}\text { życie } \\
\text { kulturalne }\end{array}$} & \multicolumn{2}{|c|}{$\begin{array}{c}\text { radzenie } \\
\text { sobie } \\
\text { w życiu } \\
\text { codzien- } \\
\text { nym } \\
\end{array}$} & \multicolumn{2}{|c|}{$\begin{array}{c}\text { udział } \\
\text { w życiu } \\
\text { społecznym } \\
\text { i politycz- } \\
\text { nym }\end{array}$} \\
\hline & 1994 & 2009 & 1994 & 2009 & 1994 & 2009 & 1994 & 2009 & 1994 & 2009 & 1994 & 2009 & 1994 & 2009 \\
\hline & \multicolumn{14}{|c|}{$(w \%)$} \\
\hline Duży & 30 & 42 & 32 & 43 & 22 & 24 & 40 & 49 & 24 & 33 & 35 & 40 & 18 & 29 \\
\hline Średni & 16 & 16 & 18 & 17 & 13 & 15 & 14 & 16 & 17 & 16 & 18 & 17 & 11 & 13 \\
\hline Mały & 45 & 37 & 41 & 36 & 57 & 57 & 30 & 30 & 43 & 47 & 41 & 41 & 47 & 50 \\
\hline $\begin{array}{c}\text { Brak } \\
\text { oceny }\end{array}$ & 8 & 5 & 9 & 4 & 8 & 4 & 16 & 5 & 16 & 4 & 6 & 2 & 22 & 8 \\
\hline
\end{tabular}

Źródło: [Rola wykesztatcenia i zmiany w jej społecznym postrzeganiu w latach 1993-2009, 2009].

Wykorzystanie umiejętności zdobytych w procesie edukacji w innych dziedzinach życia uzupełnia obraz ogólnego znaczenia przypisywanego wykształceniu. Polacy cenia edukację i dostrzegają pozytywny wpływ wykształcenia niemal na wszystkie obszary życia społeczno-zawodowego.

Przeprowadzone przez CBOS w pierwszej dekadzie XXI wieku badania opinii społeczeństwa w odniesieniu do wysokości postulowanych i postrzeganych zarob- 
ków osób przynależących do różnych grup społeczno-zawodowych oraz prezentujących różny poziom i typ wykształcenia wykazały, że w latach 1994-2004 w świadomości społecznej znacząco zmniejszyła się rozbieżność pomiędzy postrzeganymi a postulowanymi zarobkami osób z wyższym wykształceniem [Postrzegana i postulowana..., 2004]. Wyniki sondażu pokazały również, że od 1994 roku zwiększa się spostrzegana społecznie rozpiętość dochodów oraz jest silne przekonanie, że pewne grupy społeczno-zawodowe osiagaja nieadekwatnie niski poziom dochodów (np. pielęgniarki) lub zbyt wysoki (politycy). Natomiast wpływ zasad merytokratycznych był obecny w akceptacji zmian dochodów osób z wyższym wykształceniem: mimo że w opinii respondentów przedstawiciele tych zawodów wciąż zarabiają mniej niż powinni, to jednak ich dochody stają się coraz bardziej proporcjonalne do społecznych oczekiwań i zgodne z zasadą wynagradzania za kwalifikacje. Polacy zgadzają się na zróżnicowanie zarobków opartych na społecznie akceptowanych kryteriach.

W analizowanym okresie najwyższe (przeciętne) wynagrodzenia powyżej średniej krajowej otrzymywały osoby zatrudnione w zawodach należacych do trzech wielkich grup zawodów, tj.: przedstawiciele władz publicznych, wyżsi urzędnicy i kierownicy, specjaliści oraz technicy i inny średni personel (tabela 4.). W związku z tym wynagrodzenie przedstawicieli władz publicznych, wyższych urzędników i kierowników - było ponad dwukrotnie wyższe niż przeciętne wynagrodzenie ogółu badanych. Druga pod względem wysokości przeciętnego wynagrodzenia grupa pracowników byli specjaliści - ich wynagrodzenia były o około $125,0-135,0$ proc. wyższe niż przeciętne wynagrodzenie ogółu. Natomiast niewiele powyżej średniej krajowej uzyskiwali technicy i średni personel techniczny (o 3,1\% -5,5\%), jednakże w 2012 roku przeciętne wynagrodzenie dla tej grupy zawodów w niewielkim stopniu zmniejszyło się (o 0,2 pkt. proc.).

Wynagrodzenia pracowników pozostałych grup zawodów były niższe niż przeciętne wynagrodzenie brutto dla ogółu badanych. Najniższe wynagrodzenia otrzymywali pracownicy usług i sprzedawcy oraz osoby pracujące przy pracach prostych (odpowiednio: 58,2\% i 60,1\% przeciętnego wynagrodzenia dla ogółu). W wielkiej grupie zawodów - rolnicy, ogrodnicy, leśnicy i rybacy - wysokość przeciętnego wynagrodzenia wynosiła zaledwie około $67,5 \%$ przeciętnej płacy. Wyraźnie lepiej niż poprzednie grupy, choć poniżej średniej, zarabiali robotnicy przemysłowi i rzemieślnicy $(79,8 \%)$, pracownicy biurowi $(82,1 \%)$, a w grupie operatorów i monterów maszyn i urządzeń $83,0 \%$ ogółu przeciętnego wynagrodzenia. Warto zauważyć, że w latach 2004-2012 hierarchia płacowa badanych grup zawodowych w zasadzie nie zmieniała się, a wzrost wysokości wynagrodzeń w poszczególnych grupach był nierównomierny. 
TABELA 4. Przeciętne wynagrodzenia brutto według grup zawodów wykonywanych za październik w latch 2004-2012

\begin{tabular}{|c|c|c|c|c|c|c|}
\hline \multicolumn{2}{|c|}{ Grupa zawodowa } & 2004 & 2006 & 2008 & 2010 & 2012 \\
\hline \multirow{2}{*}{ Ogółem } & (w zl) & 2368,52 & 2654,13 & 3232,07 & 3543,50 & 3895,72 \\
\hline & $(\mathrm{w} \%)$ & 100,0 & 100,0 & 100,0 & 100,0 & 100,0 \\
\hline \multirow{2}{*}{\multicolumn{2}{|c|}{$\begin{array}{l}\text { Przedstawiciele władz } \\
\text { publicznych, wyżsi } \\
\text { urzędnicy i kierownicy }\end{array}$}} & 5482,11 & 5917,29 & 7219,37 & 7344,00 & 8143,2 \\
\hline & & 231,5 & 222,9 & 223,4 & 207,3 & 209,0 \\
\hline \multirow{2}{*}{\multicolumn{2}{|c|}{ Specjaliści }} & 3180,32 & 3316,84 & 3979,02 & 4327,31 & 4771,02 \\
\hline & & 134,3 & 125,0 & 123,1 & 122,1 & 122,5 \\
\hline \multirow{2}{*}{\multicolumn{2}{|c|}{$\begin{array}{l}\text { Technicy i inny średni } \\
\text { personel techniczny }\end{array}$}} & 2342,55 & 2799,95 & 3341,58 & 3652,71 & 3888,8 \\
\hline & & 98,9 & 105,5 & 103,4 & 103,1 & 99,8 \\
\hline \multirow{2}{*}{\multicolumn{2}{|c|}{ Pracownicy biurowi }} & 2021,06 & 2168,30 & 2713,47 & 2978,82 & 3197,3 \\
\hline & & 85,3 & 81,7 & 84,0 & 84,1 & 82,1 \\
\hline \multirow{2}{*}{\multicolumn{2}{|c|}{$\begin{array}{l}\text { Pracownicy usług } \\
\text { i sprzedawcy }\end{array}$}} & 1361,39 & 1480,12 & 1856,99 & 2107,36 & 2266,87 \\
\hline & & 57,5 & 55,8 & 57,5 & 59,5 & 58,2 \\
\hline \multirow{2}{*}{\multicolumn{2}{|c|}{$\begin{array}{l}\text { Rolnicy, ogrodnicy, leśnicy } \\
\text { i rybacy }\end{array}$}} & 1614,98 & 1781,07 & 1979,56 & 2203,32 & 2631,44 \\
\hline & & 68,2 & 67,1 & 61,2 & 62,2 & 67,5 \\
\hline \multirow{2}{*}{\multicolumn{2}{|c|}{$\begin{array}{l}\text { Robotnicy przemysłowi } \\
\text { i rzemieślnicy }\end{array}$}} & 1845,31 & 2178,05 & 2673,58 & 2772,46 & 3108,44 \\
\hline & & 77,9 & 82,1 & 82,7 & 78,2 & 79,8 \\
\hline \multirow{2}{*}{\multicolumn{2}{|c|}{$\begin{array}{l}\text { Operatorzy i monterzy } \\
\text { maszyn i urządzeń }\end{array}$}} & 2002,88 & 2227,08 & 2722,19 & 3006,33 & 3233,31 \\
\hline & & 84,6 & 83,9 & 84,2 & 84,8 & 83,0 \\
\hline \multirow{2}{*}{\multicolumn{2}{|c|}{$\begin{array}{l}\text { Pracownicy zatrudnieni } \\
\text { przy pracach prostych }\end{array}$}} & 1352,79 & 1524,53 & 1895,86 & 2074,15 & 2241,28 \\
\hline & & 57,1 & 57,4 & 58,7 & 58,5 & 60,1 \\
\hline
\end{tabular}

Źródło: [Rocznik Statystyczny RP, 2011; Rocznik Statystyczny RP, 2013; Struktura wynagrodzeń wedtug zawodón w październiku 2004, 2008; Struktura wynagrodzeń wedtug zawodów w październiku 2008, 2009].

Największy, względny wzrost wynagrodzeń - na przestrzeni badanych lat - nastąpił w dwóch grupach: robotnicy przemysłowi i rzemieślnicy (o 68,4\%), technicy i inny średni personel (o 66\%) oraz w dwóch niżej notowanych grupach zawodów, tj. pracownicy usług i sprzedawcy (o 66,5\%) oraz pracownicy zatrudnieni przy pracach prostych (o 65,7\%). Natomiast najniższą dynamikę wzrostu można było zaobserwować w dwóch najwyżej wynagradzanych grupach, tj.: przedstawiciele władz publicznych, wyżsi urzędnicy i kierownicy (o 48,5\%) oraz specjaliści (o 50\%).

W Polsce notuje się również dość wysoki stopień legitymizacji zróżnicowań społecznych, które wynikaja z czynników merytokratycznych (a więc osiaganych przez jednostkę, a nie przypisanych jej), [Rychard, 2008, s. 450-469]. Na potwierdzenie tych wniosków można przytoczyć wyniki kolejnych badań sondażowych CBOS, dowodzące, że w 2007 roku pracowitość była najczęściej wymieniana jako źródło bogactwa (41\% wskazań w porównaniu z 26\% w 1992 roku), [Opinie o bogactwie..., 2007]. O gotowości do podnoszenia swojej wartości na rynku pracy przez podnoszenie kwalifikacji świadczą wyniki sondażu z 2009 roku, w którym 50\% badanych zadeklarowało gotowość dalszego podnoszenia swojego wykształcenia, mimo że tylko $28 \%$ respondentów odczuwało brak kwalifikacji w zakresie aktualnie wykonywanej pracy zawodowej. 


\section{Prognoza społeczna dla polskiej merytokracji}

Wraz ze wzrostem ogólnego poziomu wykształcenia społeczeństwa polskiego i rozpowszechniania się tendencji merytokratycznych ujawniło się negatywne zjawisko stopniowego obniżania się wartości wykształcenia - wynika to m.in. z masowego upowszechniania się szkół wyższych i ekonomizacji ich działalności. Jak twierdzi Domański: Coraz wiecej ludri otraymuje myiszze mykesztatcenie, a zapotrzebowanie na trow. inteligenckie zawody nie rośnie. Z punktu widzenia systemu spotecznego jest to dysfunkcja, chociaż warto podkreślic, ¿̇e procesy

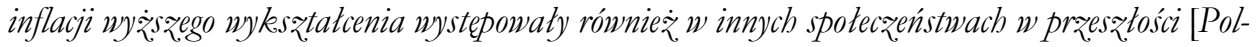
skie spotecžeństwo..., 2009]. Aktualnie posiadanie wyższego wykształcenia jest wciąż czynnikiem istotnie oddziałującym na pozycję na rynku pracy oraz strukturę dochodów. Analizy wskazują na postępujący wzrost wpływu wykształcenia na poziom wynagrodzeń: posiadanie dyplomu ukończenia szkoły wyższej łączy się z wyższymi zarobkami. Jednak przewiduja, że i ta merytokratyczna tendencja zatrzyma się w momencie, gdy zapotrzebowanie na ludzi z wyższym wykształceniem zmniejszy się, a „podaż” wyższego wykształcenia przeważy nad popytem. O przejawach zjawiska tzw. inflacji wyższego wykształcenia można obecnie mówić w sferze rekrutacji na stanowiska wysokospecjalistyczne oraz menedżerskie, zaś zjawisko to nie dotarło jeszcze do sfery wynagrodzeń. Według przytoczonych badań - tylko 37 proc. ludzi, którzy kończą wyższe studia, pracuje w tradycyjnie rozumianych zawodach inteligenckich. Natomiast coraz więcej absolwentów przechodzi do sfery prywatnego biznesu czy też wyjeżdża za granicę. W percepcji społecznej inteligencja znajduje się tradycyjnie i niezmiennie na szczycie drabiny społecznej, ma to również miejsce w systemie gospodarki wolnorynkowej. Wśród nowych inteligentów pracujących w lukratywnych zawodach i prezentujących styl życia zorientowany na sukces obserwuje się osiaganie wysokich zarobków oraz ciagły rozwój zawodowy, powszechna jest także potrzeba realizacji inteligenckiego etosu. Jednocześnie wyłania się kategoria osób z formalnym wyższym wykształceniem, które jednak nie identyfikują się z inteligencją w jej społeczno-kulturowych aspektach, a dyplom jest dla nich jedynie certyfikatem, z którym nie wiedzą dokładnie co zrobią [Polskie społeczeństwo..., 2009]. Powiększenie się tej drugiej kategorii pracowników to zarazem czynnik, jak i skutek inflacji wyższego wykształcenia.

\section{Podsumowanie}

$\mathrm{Na}$ podstawie powyższych analiz można wnioskować, że w społeczeństwie polskim po 1989 roku coraz bardziej powszechne stawało się przekonanie o wpływie zasad merytokratycznych na osiagniecie sukcesu życiowego: satysfakcjonującej pozycji zawodowej oraz oczekiwanego poziomu dochodów. Dokonujący się po 1989 roku „skok edukacyjny", widoczny przede wszystkim w zmianie strukturalnej społeczeństwa polskiego pod względem wykształcenia, można uznać za odzwierciedlenie tendencji merytokratycznych. Charakterystyka rodzącej się w Polsce merytokracji pozwala wpisać ją w teorię funkcjonalistycznej koncepcji nierówności społecznych Davisa 
i Moore’a, gdyż mimo że w społecznej świadomości obecne są pozostałości poprzedniego systemu: pozaosobiste cechy jednostek (protekcja, zamożność środowiska pochodzenia) wciąż są wymieniane wśród warunków wpływających na osiagniecie sukcesu, to jednak przypisuje się im mniejsze znaczenie niż zasobom indywidualnym: kompetencji i fachowości.

W przyszłości ludzie powinni - jak sądzą autorzy tego artykułu - więcej niż kiedyś polegać na sobie, gdyż w społeczeństwie opartym na wiedzy drogi indywidualnego awansu związanego z wymarzona pozycją nie wyznacza już tylko protekcja i pochodzenie społeczne. Postępujące przemiany w kierunku merytokracji mogą dostarczyć większych możliwości wykorzystywania indywidualnego kapitału, zapewniając tym samym lepsze szanse zdolnym i inwestującym w siebie jednostkom. Jednocześnie strategie edukacyjne Polaków powinny być bardziej elastyczne i dopasowane do wymagań rynkowych społeczeństwa opartego na wiedzy, wsparte etosem inteligenckim i zawodowym.

\section{Literatura}

Beskid L. 1999 Zmiany w życiu Polaków w gospodarce rynkowej, IFiS PAN, Warszawa. Czy warto sie uczyc? 2007, Komunikat z badań BS 072/07, CBOS, Warszawa.

Domański H. 2000 Hierarchie i bariery spoteczne w latach dziewiéćdziesiatych, ISP, Warszawa.

Domański H. 2004a Struktura społeczna, Wydawnictwo Scholar, Warszawa.

Domański H. 2004b Zmiany struktury społecznej i systemu wartości, [w:] Cay wartości spoteczne sq barierq reform UE?, Forum: Wartości i Rozwój, nr 1, Instytut Badań nad Gospodarką Rynkowa, Gdańsk.

Elementy teorii socjologicznych 1975, W. Derczyński, A. Jasińska-Kania, J. Szacki (red.), Wydawnictwo Naukowe PWN, Warszawa.

Hamilton M., Hirszowicz M. 1995 Klasy i nierówności spoteczne w perspektywie porównawczej, ISPAN, Warszawa.

Narodowy Spis Powszechny Ludności i Mieszkeań 2002 2003, GUS, Warszawa.

Narodowy Spis Powszechny Ludności i Mieszkean 2011 2012, GUS, Warszawa.

Opinie o bogactwie i ludziach bogatych 2007, Komunikat z badań BS/101/07, CBOS, Warszawa.

O stylach życia Polaków 1997, M. Falkowska (red.), CBOS, Warszawa.

Opinie o zasadach przyjmowania na studia wyższe 1984, Komunikat z badań nr 37/351, OBOP SA, Warszawa.

Pierwsza dekada niepodległości 2001, E. Wnuk-Lipiński, M. Ziółkowski (red.), ISPAN, Warszawa.

Polacy o swoim wykesz̨tatceniu - wřrost niezadowolenia 2002, Komunikat z badań BS/192/2002, CBOS, Warszawa.

Polskie społeczeństwo po 1989 roku z. Henrykiem Domańskim rozmawia Jakub Biernat, dokument elektroniczny, tryb dostępu: [www.fakt-opinie.salon24.pl/100568,profhenryk-domanski-ifis-pan-polskie-spoleczenstwo-po-1989-r., data wejścia: 22.03.2009]. 
Postrzegana i postulowana uysokosśc zarobków 2004, Komunikat z badań BS/103/2004, CBOS, Warszawa.

Rocznik Statystyczny 1991, GUS, Warszawa.

Rocznik Statystyczny RP 2011, GUS, Warszawa.

Rocznik Statystyczny RP 2013, GUS, Warszawa.

Rola wyleształcenia $i$ zmiany w jej spotecznym postrzeganiu w latach 1993-2009 2009, Komunikat z badań BS/163/09, CBOS, Warszawa.

Równość syccionyych szans 1999, Komunikat z badań BS/48/99, CBOS, Warszawa.

Rychard M. 2008 Socjologiczne uwarunkowania rozwoju przestrzennego Polski. Ekspertysy do Koncepcii Przestrzennego Zagospodarowania Kraju 2008-2033, t. IV, Ministerstwo Rozwoju Regionalnego, Warszawa.

Struktura mynagrodzeñ wedtug zawodów w paźdrierniku 2004 2008, GUS, Warszawa.

Struktura wynagrodzen wedtug zawodów w październiku 2008 2009, GUS, Warszawa.

Studia ny:šre - dla kogo po co i zjakim skutkiem 2013, Komunikat z badań BS/092/2013, CBOS, Warszawa.

Wiatr J. 1999 Socjologia wielkiej przemiany, Krajowa Agencja Promocyjna, Warszawa.

Wykesztatcenie ma znaczenie? 2013, Komunikat z badań BS/096/2013, CBOS, Warszawa.

Warost aspiracii edukacyjnych Polaków w latach 1993-2004 2004, Komunikat z badań BS/81/2004, CBOS, Warszawa.

Ziółkowski M. 2005 O pewnych konsekwencjach cześciowego i niekonsekwentnego utowarowienia polskiego sækolnictwa wy ¿̇szego, „Nauka”, z. 2/25.

Życie codzienne wśród Polaków 2003, R. Sulima (red.), Oficyna Wydawnicza Stopka, Łomża. 